The aim of the study was to evaluate the patient's psychological state in the ad vanced stage of cancerous disease and to assess the effect of sustenance provided by the nursing personnel upon the emotional state of the patient.

Material and methods: The study group comprised 46 subjects treated in palliative care medical wards in Łódź. The data were collected in accordance with the HADS-M questionnaire as well as a self-developed survey. The information obtained was analysed by means of Pearson $\chi^{2}$ test.

Results: The results obtained indicate that most subjects undergo mood aggravation. $76.2 \%$ of patients were diagnosed with depressive states. Only $19.6 \%$ of the population under investigation showed no signs of anxiety states. The study demonstrates irritation to be yet another unfavourable emotional state coupled with the advanced stage of cancerous disease with as few as $4.4 \%(4.2 \%)$ respondents claiming not to suffer any such symptoms. The patients highly prize the support they receive and it notably improved their well-being. Social support is essential in the advanced stage of the disease. Less severe mental disorders were noted in people who have received all kinds of support.

Key words: cancerous disease, terminal stage, support, emotional state.

\section{Evaluation of the psychological state of patients with advanced cancer and the impact of support on their emotional condition}

Jolanta Glińska ${ }^{1}$ Ewa Adamska' ${ }^{1}$, Małgorzata Lewandowska', Józef Kobos²

${ }^{1}$ Faculty of Nursing Care Education, Medical University of Lodz, Poland

${ }^{2}$ Chair of Biomedical Basis of Nursing, Medical University of Lodz, Poland

\section{Introduction}

The continuous rise in the number of cancer patients evokes concern over their present and future life quality, which is abated by the fact of diagnosis [1]. Cancerous disease triggers a spate of psychological difficulties in response to the predicament they are facing. The terminal stage of the disease in question involves both the aggravation of physiological functions of the organism and the growing painfulness which in turn leads to the patient's loss of interest in contacting the environment. These facts have been confirmed by many studies, according to which anxiety, depression, fatigue and pain are symptoms affecting quality of life [2]. Especially a low quality of life, both in the emotional and physical sphere, is observed in patients with advanced stage of disease [3]. The condition of the patients is difficult, not only for them, but also for their families and caregivers [4, 5]. The reality of the great suffering surrounds the patient and his/her immediate family members, embraces and permeates all aspects of their life. In the face of death the patient loses his/her family position and social position, which combines with changing values and ideals. Neither the patients nor their families are prepared for a new, hard life situation; therefore during patient care the psychological and emotional needs of immediate persons should not be forgotten [6, 7]. In the time of changes the family, as a stabilising factor, requires strengthening from the outside. This support exerts a significant impact on the functioning of the patient and his family and gives the satisfaction, hope and motivation to fight the disease [8]. Team work provides the opportunity to distribute the burden of care, responsibility, stress alleviation, and mutual support onto multiple parties. The nurses are the coordinators of the process of patient effective reassurance in all its aspects as they are in constant and intimate contact with the patients themselves, their families, volunteers as well as all other members of the therapeutic team. The support provided by the term may be differentiated, in terms of scope, into instrumental, emotional, appraisal, informational and tangible. The effective care programme requires one to see human health care problems in all their complexity and to consider not only biophysical changes but also those which are defined as psychosocial. One means of comforting the said patients features hospices that are set on ascertaining the optimal life quality in all the spheres of the patients' functioning.

\section{Aim of the study}

The aim of the study is to furnish an answer to the following questions: 1. Which psychological difficulties are the most awkward to a patient in the terminal stage of cancerous disease? 


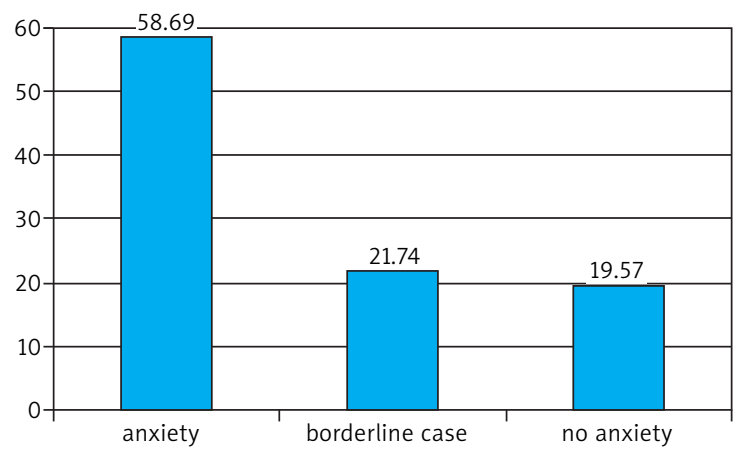

Fig. 1. Anxiety states in subjects in the advanced stage of the disease

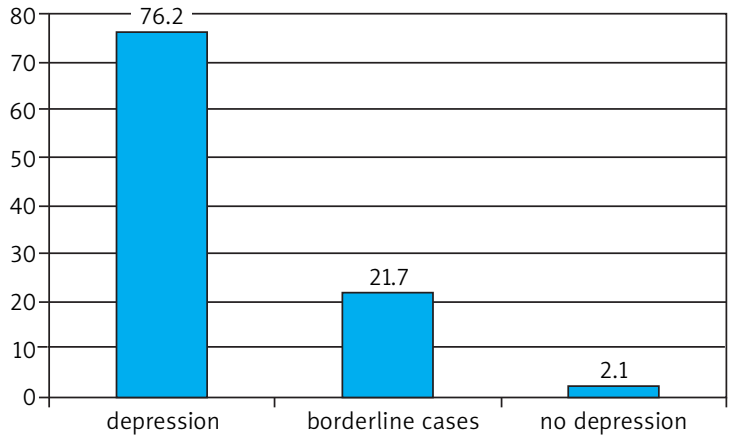

Fig. 2. Depression-related states in subjects in the advanced stage of the disease

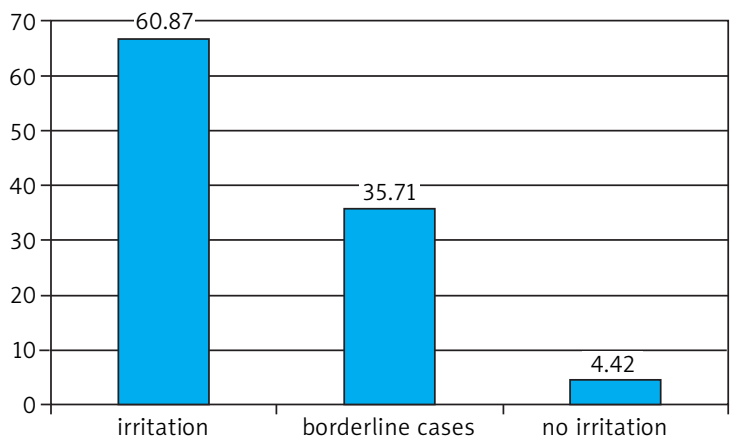

Fig. 3. Irritation states in subjects in the terminal stage of the disease

2. What is the patients' evaluation of the support provided by the nursing staff?

3. Is there a correlation between the support received and the psychological state of the patient?

\section{Material and methods}

The study was conducted in the palliative care medical wards in Łódź in 2009. For the purpose of psychological state evaluation the HADS-M questionnaire was implemented as adapted for Polish standards by M. Majkowicz, K. de Walden-Gałuszko and G. Chojnacka-Szawłowska. The survey consisted of three groups of questions. The first category contained questions about anxiety, the second relat- ed to the states of depression and the third examined states of irritation. Other data were assessed in accordance with a self-developed survey. The questionnaire of the survey included 38 questions: 22 questions related to physical symptoms attributable to cancer, 11 questions concerned forms of social support and its quality, the following questions related to nursing care and its impact on the quality of life, and the remaining questions determined demographic data. The research was conducted after obtaining the consent of the Bioethical Commission (no. RNN/404/08/KB). The influence of the support on emotional state of the patient was analysed by means of the non-parametric Pearson $\chi^{2}$. The statistical significance level was set at $p<0.05$.

\section{Results}

The study group comprised 46 subjects treated in the palliative care medical wards in tódź. The questionnaires were presented to patients with preserved verbal and logical contact. The subjects ranged in age from 30 to 65 years.

Over $50 \%$ of pollees were aged over 65 years. Young people constituted $13 \%$. The distribution with regard to sex proved even. The percentage of males was $47.8 \%$ and females $52.2 \%$. All subjects were urban residents.

In the first part of the study the focus was on the emotional state of the patients. The results of the analysis are presented in Figs. 1-3. The problem associated with the occurrence of anxiety was found in the majority of those investigated, which was very often accompanied by edginess, panic and fear. Depression is another accompanying symptom in the group of respondents. Patients pointed to the negative experiences associated with the disease as sadness and despondence.

Because of the health status in more than half of the patients the loss of optimism and self-confidence was shown, which resulted in frequent outbursts of anger and irritation. The study points to the prevalence of depression out of all three considered states (anxiety, depression, irritation) in the investigated group. Anxiety was found to be the least frequently occurring.

Next to be investigated was the evaluation of appraisal support received from the nursing personnel and the patients' expectations towards the professional group in question. The results obtained are shown in Figs. 4-8.

The respondents' reactions indicate that the most numerous group of them were granted instrumental (71.7\%) and emotional (65.2\%) support. There was the least satisfaction with the level of informational support they received. In most cases, informational support proved to be low and superficial and thus failed to meet the patients' expectations.

The majority of patients share the opinion that nursing care favourably affects their quality of life. The respondents' reactions indicate that nursing care was helpful both in alleviating unpleasant physical ailments and in improving peace of mind. Only a marginal percentage endorsed a conviction to the contrary (Fig. 9). The majority of patients (87\%) indicate a lowered psychical mood.

In the last stage we attempted to answer the question whether there is a likelihood of the impact of support upon the emotional state of patients (Fig. 10). 


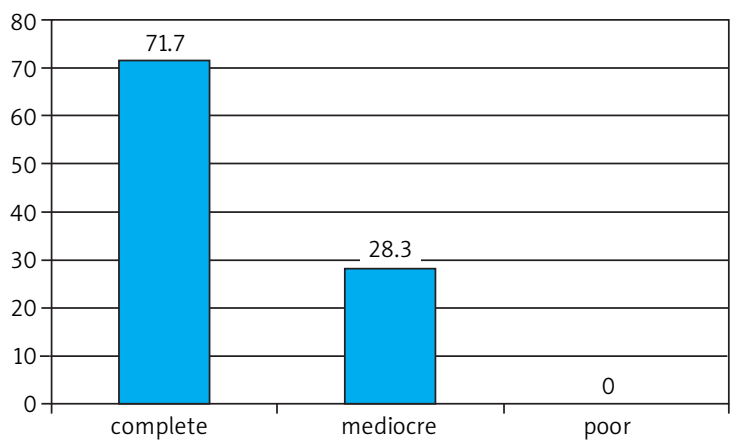

Fig. 4. Evaluation of emotional support as received from the nursing personnel

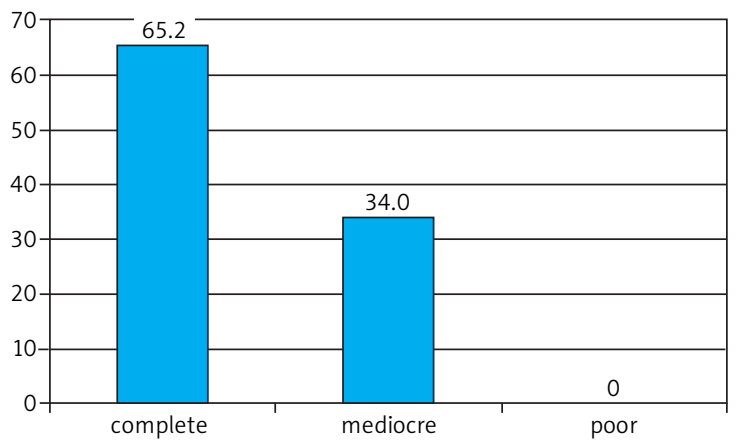

Fig. 6. Evaluation of appraisal support as received from the nursing personnel

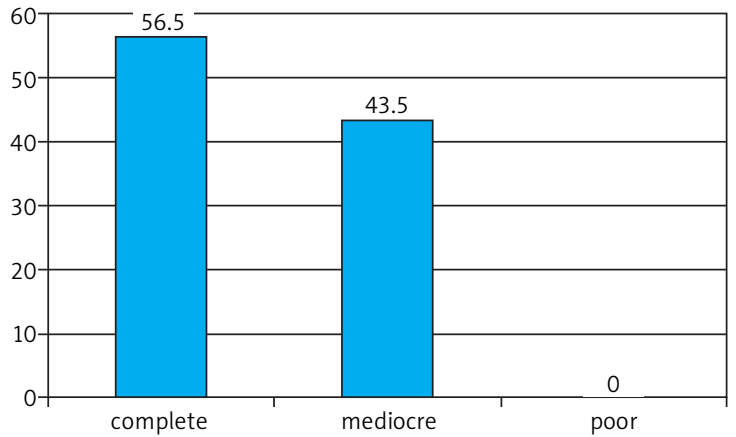

Fig. 8. Evaluation of medical support

As may be inferred from the data collected in the Table 1 , the types of support to have the most notable effect on all kinds of disorders include informational, emotional and appraisal support, which were those at the level $p<0.001$. The percentage of people with anxiety and depression decreased as emotional support and appraisal support were provided. The statistical significance was shown to be at $p>0.001$ between informational support and all kinds of disorders. Appraisal support was significant. A lower value of $p<0.05$ was assumed between instrumental support and psychical state of those investigated. A statistically non-significant value was assumed between researched states and tangible support.

It is for this reason that, having borne in mind the dissatisfaction of the patients with the level of informational

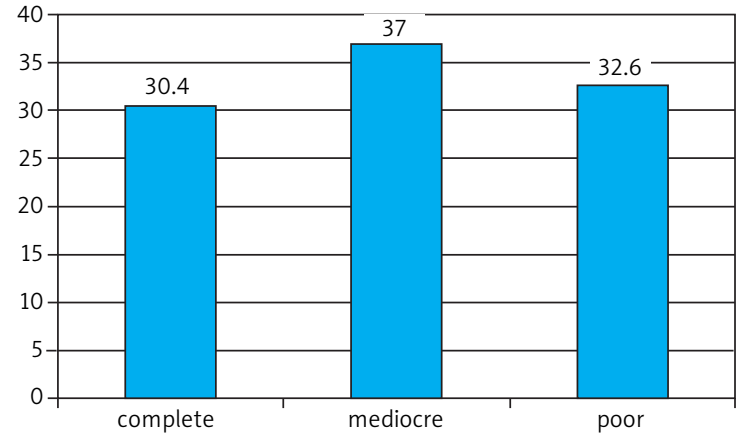

Fig. 5. Evaluation of informational support as received from the nursing personnel

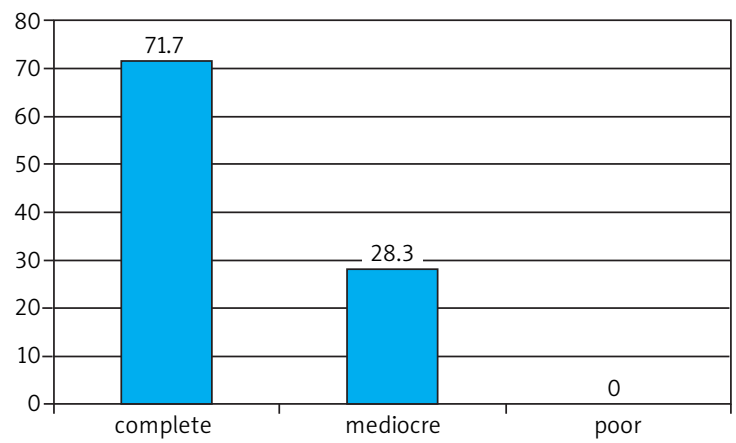

Fig. 7. Evaluation of instrumental support

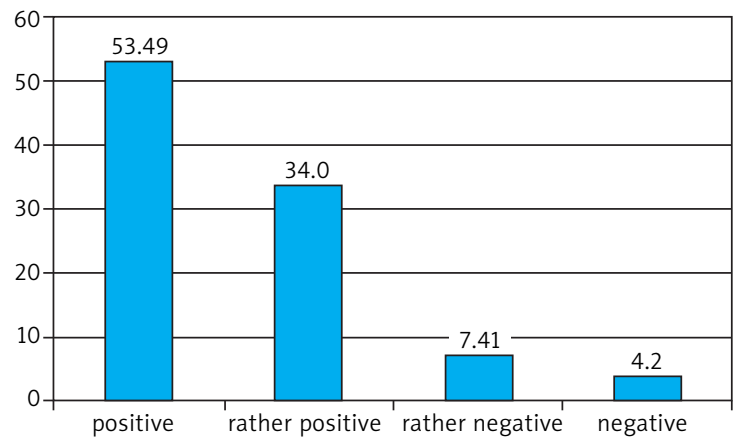

Fig. 9. Evaluation of the impact of nursing care upon the life quality in subjects in the terminal stage of the disease

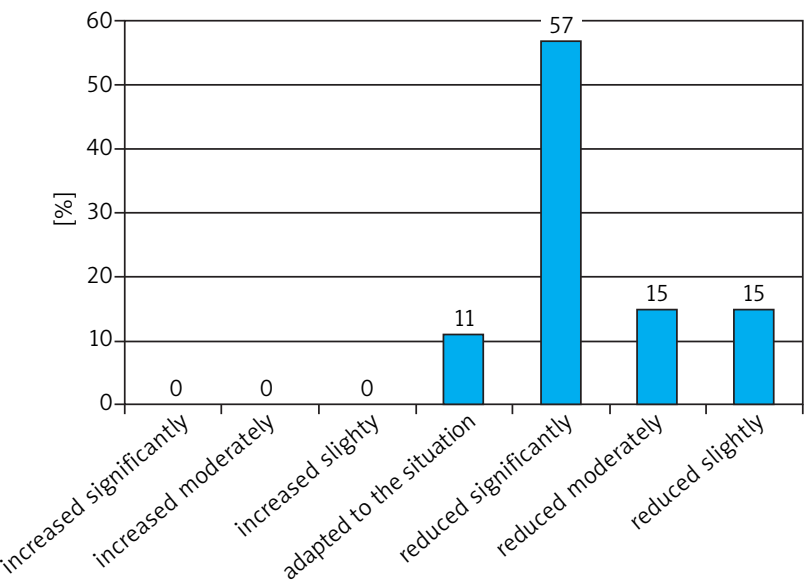

Fig. 10. Evaluation of the psychical mood in subjects in the advanced stage of the disease 
Table 1. The outcome of the statistical analysis of the impact of various types of support upon the emotional state of a patient in the terminal stage of disease

\begin{tabular}{|c|c|c|c|}
\hline Type of support & Depression & Anxiety & Irritation \\
\hline emotional & $\begin{array}{c}\chi^{2}=32.84 \\
\mathrm{df}=9 \\
p<0.001\end{array}$ & $\begin{array}{c}\chi^{2}=35.04 \\
\mathrm{df}=9 \\
p<0.001\end{array}$ & $\begin{array}{c}\chi^{2}=57.22 \\
\mathrm{df}=9 \\
p<0.001\end{array}$ \\
\hline informational & $\begin{array}{c}\chi^{2}=28.22 \\
d f=9 \\
p<0.001\end{array}$ & $\begin{array}{c}\chi^{2}=33.51 \\
\mathrm{df}=9 \\
p<0.001\end{array}$ & $\begin{array}{c}\chi^{2}=90.99 \\
\mathrm{df}=9 \\
p<0.001\end{array}$ \\
\hline instrumental & $\begin{array}{c}\chi^{2}=9.35 \\
\mathrm{df}=9 \\
p<0.05\end{array}$ & $\begin{array}{c}\chi^{2}=21.97 \\
\mathrm{df}=9 \\
p<0.05\end{array}$ & $\begin{array}{c}\chi^{2}=16.88 \\
\mathrm{df}=2 \\
p<0.001\end{array}$ \\
\hline tangible & $\begin{array}{c}\chi^{2}=1.65 \\
\mathrm{df}=9 \\
p>0.05\end{array}$ & $\begin{array}{c}\chi^{2}=7.34 \\
d f=9 \\
p>0.05\end{array}$ & $\begin{array}{c}\chi^{2}=18.87 \\
\mathrm{df}=3 \\
p<0.001\end{array}$ \\
\hline appraisal & $\begin{array}{c}\chi^{2}=46.09 \\
d f=6 \\
p<0.001\end{array}$ & $\begin{array}{c}\chi^{2}=27.12 \\
\mathrm{df}=6 \\
p<0.001\end{array}$ & $\begin{array}{c}\chi^{2}=76.89 \\
\mathrm{df}=9 \\
p<0.001\end{array}$ \\
\hline
\end{tabular}

support provided, greater pressure should be put on the conversation with the patient and responding to the patients' queries in a clear, intelligible and anticipated manner.

\section{Discussion}

The fact of rescue and extension of life increases the number of people with chronic diseases, that determine many of the psychological stresses. Therefore modern medicine increasingly emphasises not only extension of patients' life but also its quality. It creates the need to emphasise the appropriate psychosocial care, the purpose of which is to ensure the longest period of high quality before death. The most important is to provide medical care and emotional support to patients in the terminal stage of cancerous disease [10]. The needs of a patient in the terminal stage of cancerous disease are to be considered in tangible, emotional, social and spiritual terms [4]. The study presented here centres on the salience of the psychological dimension in the overall structure of the life quality in patients in the terminal stage of disease. According to K. de Walden-Gałuszko chronic disease gives rise to a number of emotional reactions. They predominantly comprise negative feelings such as anxiety, depression, anger, and melancholy [11]. Cancerous disease spurs variegated negative psychological responses to the predicament they are facing. The incidence of psychological disorders reaches over $60 \%$ of cases of patients in an advanced stage of cancerous disease [12]. Numerous different reasons may lead up to the development of unfavourable psychological conditions [13]. One consists in the diagnosis of cancerous disease and the concomitant lifestyle change, social role alteration, and concern with the future prosperity of the patient's family. Others concern the change in outside appearance, impairment of vital organ functions, the pain accompanying the disease as well as pharmacological therapy, diagnostic procedures performance and the prolonged hospitalization [14]. On the strength of the analysis of the heretofore gathered information it emerges that a decreased mood occurs in the majority of patients, irrespective of their age and disease duration. The negative outcome of the terminal stage of cancerous disease that takes the form of depression was observed in most subjects under study (76.2\%). Similar effects were noted by Eleonora Mess et al. They reveal as many as $74 \%$ of patients to evince decreased mood and symptoms of depression and $92 \%$ to have been reluctant to come to terms with the disease and the consequent condition [15]. In the literature on the subject the findings diverge in respect of the size of the problem at hand, pointing to both small and large percentages. However, most authors point to percentages above $60 \%$ [11, 15-18].

In the advanced stage of cancerous disease depression may be accompanied by anxiety syndrome as an expression of the growing acuteness of the symptoms of the disease as well as the concerns over the patient's own life. According to Rogowicz the subject involved experiences emotions from distress, through anxiety, to terror [19]. Anxiety in the terminal stage of the disease stems from the prospective final analysis of one's life as well as the species survival instinct and the instinct for self-preservation that is associated with the feeling of terror [20]. Anxiety manifests itself on three planes - psychological, behavioural and vegetative-somatic. In psychological terms anxiety elicits tension, distress and the inability to relax. It may manifest through concentration disturbance or reduced intellectual capacities. Its behavioural expression consists in a range of symptoms from excitation to psycho-motor arrest. Immediate signs may include facial expression, timbre change as well as trembling of the hands.

Vegetative symptoms of anxiety involve the feeling of dryness in the mouth, excessive perspiration, heightened pulse and accelerated respiration, augmented arterial blood pressure, increased muscular tension, insomnia-related conditions as well as nightmares. Somatic effects may include abdominal pain, diarrhoea, and frequent urge to urinate. The research revealed anxiety states to occur in $58.7 \%$ of subjects enrolled in the study and borderline cases in $21.7 \%$. Only a marginal percentage of $19.6 \%$ of the patients under investigation showed no distressing signs. Hopwood obtained 
slightly lower values with anxiety states present in $24 \%$ of patients and depression in $18 \%$. In addition, he found anxiety to affect at least $1 / 3$ of the families suffering from the terminal disease of immediate family members [21, 22].

Psychological support proves significant in the suppression of anxiety and depression in patients in the terminal stage [23]. Many authors point to the importance of support in care-giving [24-26]. The nurse is a companion and a guide in the hard process of merging own identity. The best method features conversation by virtue of which the origin of the anxiety that affects the subject may be traced back as well as various relaxation techniques aimed at removing tension and distress. The objective of the caregiver is to earn the patient's trust through constant charitable presence and patient listening to the patient's qualms. To cite de WaldenGałuszko's words, the fundamental method recommended in all states of emotional discomfort involves catharsis - a skilful encouragement towards 'getting it off your chest' or the method of 'distraction' - that is, diverting attention from the sorrowful feelings. In the available literature on the subject of psychological support such expressions may be encountered as 'therapy through conversation' [27]. Moreover, it is of vital importance to be ready to adjust to the dynamics of the patient's change of attitudes and reactions along with the observation of his/her behaviour and the readiness to bring comfort [28]. All mentioned procedures are targeted at securing the patient's feeling of safety, emotional calm and his/her preparation for the constant aggravation of their medical condition [29]. In the research as many as $71.7 \%$ of patients were found to be entirely satisfied with the emotional support provided by the nursing personnel. The statistical significance was shown to be at $p<0.001$. The percentage of patients with anxiety and depression dropped in response to the emotional and appraisal support supplied. A strong statistical significance estimated at $p>0.001$ was shown to hold for the interdependence of informational support and the above-mentioned syndromes. Appraisal support proved to be of considerable statistical significance as well. A less significant correlation of $p<0.05$ was detected between instrumental support and the subjects' psychological state. No statistical significance was found between the conditions in question and tangible support.

Irritation constitutes yet another symptom of cancerous disease. The analysis of research studies indicated that it affects $60.7 \%$ (60.1\%) of subjects with a further $35.7 \%$ of patients manifesting borderline cases. In as few as $4.4 \%$ of respondents no such signs were observed. In this particular case all types of support proved to exert a beneficial influence on the psychological state of the patients. Irritation affected mostly those patients who were left alone. The said group of subjects complained about the brevity of time expended by the nursing care in showing support and that it falls below their expectations.

The replies to the questionnaire as furnished by the patients under study indicate that over half of the group examined (53.5\%) hold nursing care in high regard and appreciate its favourable influence on their life quality. Authentic care for the patient has a beneficial effect - as the patients themselves confirm - on the patient's life quality. How- ever, the results obtained are not satisfactory since the remainder of subjects see room for more nursing care in the health care giving process. The studies by other authors indicate that patients who receive support from a palliative care team obtain a much higher level of support as well as pain alleviation than patients who confine themselves to the services of the family physician and the community nurse [30, 31]. However, as Desmedt, Michel and Twycross state, most patients wish to die at home and avail themselves only of the assistance of the family physician and a community nurse with training in the field of palliative care [32, 33]. Currently, around the world the need to change care by adopting the integrated approach to identifying and responding to the psychosocial needs of patients in support is emphasised.

In conclusion: In more than half of subjects under investigation all three disorders were present, namely anxiety, depression and irritation. The patients highly rate the received instrumental and emotional support. Social support plays a key role in the terminal stage of cancerous disease. Milder psychological disorders were observed in subjects who received all kinds of support.

The authors declare no conflict of interest.

\section{References}

1. Zielińska-Więczkowska H, Betłakowski J. Jakość życia pacjentów z chorobą nowotworową poddanych chemioterapii. Wspolczesna Onkol 2010; 14: 276-80.

2. Henoch I, Bergman B, Gustafsson M, Gaston-Johansson F, Danielson $\mathrm{E}$. The impact of symptoms, ability to cope with stress and social support on quality of life experiences while in patients with lung cancer. Symptom Manage Pain J 2007; 34: 370-9.

3. Jasińska M, Tracz M, Kurczewska U, Orszulak Michalak D. Ocena zmian jakości życia pacjentów w terminalnej fazie choroby nowotworowej. Wspolczesna Onkol 2010; 14: 333-9.

4. Song JI, Shin DW, Choi JY, et al. Quality of life and mental health in family caregivers of patients with terminal cancer. Support Care Cancer 2011; 19: 1519-26.

5. McLean LM, Walton T, Matthew A, Jones JM. Examination of couples' attachment security in relation to depression and hopelessness in maritally distressed patients facing end-stage cancer and their spouse caregivers: a buffer or facilitator of psychosocial distress? Support Care Cancer 2011; 19: 1539-48.

6. Zielińska-Więczkowska H, Betłakowski J. Pomiar i ocena wsparcia społecznego u pacjentów hospitalizowanych poddanych chemioterapii. Wspolczesna Onkol 2010; 14: 229-32.

7. Sproul S. Celebration on Saturday to mark key role of hospice care. Inland Valley Daily Bulletin. Ontario 2011.

8. Buczkowski K, Krajnik M. Postępowanie lekarza rodzinnego wobec chorych na raka w ostatnich dniach życia. Pol Med Paliat 2003; 2: 241-50.

9. Merport A, Bober SL, Grose A, Recklitis CJ. Can the distress thermometer (DT) identify significant psychological distress in long-term cancer survivors? A comparison with the Brief Symptom Inventory-18 (BSI-18). Support Care Cancer 2012; 20: 195-8.

10. Friedrichsen $M$, Lindholm A, Milberg A. TERMINAL CHANCER; Fury as Cameron dismisses charity's fears over pounds 94 cut in cancer patients' benefits. Palliat Support Care 2011; 9: 173-81.

11. De Walden-Gałuszko K. Psychologiczne następstwa leczenia chorych na nowotwory. Onkol Pol 1998; 3: 149-52.

12. Cherny NI, Coyle N, Foley KM. Suffering in the advanced cancer patient: a definition and taxonomy. J Palliat Care 1994; 10: 57-70.

13. De Walden-Gałuszko K. Zespół depresyjny u chorych w stanie terminalnym. Polska Med Paliat 2003: 2: 87-91. 
14. Jarosz J. Opieka paliatywna w onkologii. Przegl Urol 2006; 7: 72-8.

15. Mess E, Szmyd K, Wójcik D, Kempińska E. Jakość życia pacjentów w terminalnej fazie choroby nowotworowej. Onkol Pol 2005; 8: 158-61.

16. Massie MJ, Popkin MK. Depressive disordes. In: Psycho - Oncology. Holland JC (ed.). Oxford University Press, New York 1998; 518-40.

17. De Walden-Gałuszko K. Prevalence of psychological morbidity in terminally cancer patients. Psychooncology 1996; 5: 45-9.

18. Cherny N, Coyle N, Foley KM. Suffering in the advanced cancer patient. Definition and taxonomy. J Palliat Care 1994; 10: 57-70.

19. Rogowicz M. Trwoga pacjentów w terminalnej fazie choroby nowotworowej. Medycyna Paliatywna w Praktyce 2008; 2: 108-10.

20. Makselon J. Struktura wartości a postawa wobec śmierci. Katolicki Uniwersytet Lubelski, Lublin 1983; 49-57.

21. Franks PJ, Salisbury C, Bosanquet N, Wilkinson EK, Lorentzon M, Kite S, Naysmith A, Higginson IJ. The level of need for palliative care: a systematic review of the literature. Palliat Med 2000; 14: 93-104.

22. Łuczak J, Kotlińska-Lemieszek A, Bączyk E. Somatyczne aspekty cierpienia. Wspołczesna Onkol 2000; 4: 224-30.

23. Razavi D, Stiefel F. Psychiatric discords in cancer patients. In: Supportive Care in Cancer: a Handbook for Oncologists. Klastersky J, Schimpff SC, Senn HJ (eds.). Marcel Dekker Inc, Basel. 1999; 345 370.

24. Regan M, Ristevski E, Jones R, Breen S, Hartney A. Examining the introduction of a supportive care screening and referral process for cancer patients: how does practice compare with protocols? Support Care Cancer 2012; 20: 119

25. Zarzycka D. Pielęgnowanie - istota profesjonalnego pomagania. Pielęg Położna 1998; 9: 4-6.

26. Beckstrand RL, Moore J, Callister L, Bond AE. Oncology nurses' perceptions of obstacles and supportive behaviors at the end of life. Oncol Nurs Forum 2009; 36: 446-53.

27. Janiszewska J. Dobra komunikacja warunkiem wsparcia psychicznego chorych umierających. Nowa Med 2004; 2: 69-70.

28. De Walden-Gałuszko K. Jak skutecznie pomagać chorym umierającym - problemy wsparcia psychicznego. Nowa Med 2004; 2: 67-68.

29. Krzyżanowski D, Chybicka A. Psychoonkologiczne aspekty cierpienia osoby w terminalnym okresie choroby. Onkol Pol 2007; 10: 153-5.

30. Wilkinson EK, Salisbury C, Bosanquet N, Franks PJ, Kite S, Lorentzon $M$, Naysmith A. A patient and cancer preference for, and satisfaction with specialist models of palliative care; a systematic lit erature review. Pall Med 1999; 13: 197-216.

31. Desmedt M, Michel H. Palliative home care: improving co - operation between the specialist team and the family doctor. Support Care Cancer 2002; 10: 343-8.

32. Twycross RG. Wyzwania opieki paliatywnej. Pol Med Paliat 2003; 2: 39-48.

33. Łuczak J. Cierpienie. Charakterystyka, rozpoznanie, wspomaganie cierpiących, powinności leczących, skuteczność pomocy cierpiącym chorym. In: Człowiek nieuleczalnie chory. Block B, Otrębski W (eds.) Katolicki Uniwersytet Lubelski, Lublin 1997; 68-95.

34. Surbone A, Baider L, Weitzman TS, Brames MJ, Rittenberg CN, Johnson J; MASCC Psychosocial Study Group. Psychosocial care for patients and their families is integral to supportive care in cancer: MASCC position statement. Support Care Cancer 2010; 18: 255-63.

\section{Address for correspondence}

Jolanta Glińska, MD Phd

Faculty of Nursing Care Education

Medical University of Lodz

ul. Narutowicza 58

90-136 Łódź

Submitted: $\quad$ 14.12.2011

Accepted: $\quad 1.12 .2012$ 